\title{
The Impact of the Academic Advising Style on the Development of an Academic Integrity Culture among Future PhD Candidates
}

\author{
Petro M. Boychuk, Olha L. Fast, Olha P. Shevchuk, \\ Tetiana V. Horobets and Vasyl A. Shkoba \\ The Municipal Higher Educational Institution "Lutsk Pedagogical College" of \\ the Volyn Regional Council, Lutsk, Ukraine \\ https://orcid.org/0000-0001-7451-1995 \\ https://orcid.org/0000-0001-7216-0044 \\ https:// orcid.org/0000-0002-5499-9548 \\ https:// orcid.org/0000-0002-1821-1119 \\ https://orcid.org/0000-0003-0441-2363
}

\begin{abstract}
Our research studied the impact of academic advising style on the development of a culture of academic integrity among PhD candidates. The study involved 52 postgraduate students and their 52 academic advisors. The results obtained were analyzed through general scientific methods. We used a closed-ended questionnaire to gather data from academic advisors, open-ended questions for postgraduate students, mathematical data processing techniques, and the Statistica software package to interpret data. The empirical data indicates that a pastoral academic advising style was applied by $17,3 \%$ of advisors, a laissez-faire style by $11,5 \%$, a contractual style by $40,4 \%$, and a directorial style by $30,8 \%$ of advisors in this study. Correlating these results with data on postgraduate students' level of academic integrity culture lead to the conclusion that the contractual style of academic advising could be regarded as the most beneficial for raising the level of academic integrity culture of postgraduate students (33,3\% of students of advisors with this style had a high level of academic integrity culture). The weakest style for improving the level of academic integrity culture of students is the pastoral style $(11,1 \%)$. Moreover, it is obvious that most academic advisors $(40,4 \%)$ use the mutually beneficial contractual style. The quantitative increase of advising style indicators corresponding to the contractual type entails higher values for students' academic integrity culture. The relationship between advising style and level of academic integrity culture is not linear, and we cannot argue that an academic advisor with a contractual leadership style adheres to all the desirable principles of academic integrity culture. Further investigations are required if more specific and diversified conclusions are to be made. Furthermore, we should take into account that other members of the
\end{abstract}


academic staff also have an impact on the formation and improvement of the academic integrity culture of postgraduate students.

Keywords: postgraduate studies; training $\mathrm{PhD}$ candidates; academic advisor; scientific advising styles; academic integrity culture; education quality assurance

\section{Introduction}

In recent years, academic dishonesty has become a major problem throughout the educational space (Sheard et al., 2018). Academic dishonesty refers to behaviour that is aimed at providing or receiving information from others, using unauthorized materials, and circumventing an authorized evaluation process in an academic context (Faucher \& Caves, 2009). Sefcik et al. (2019, p. 35) emphasize the need for "growing global recognition of the importance of academic integrity," and for higher education institutions to "redouble their efforts to address academic integrity issues." Adherence to the foundations of academic integrity should become well-established institutional policy in higher education institutions (Artyukhov \& Liuta, 2017). Bretag (2018) notes that academic integrity is much more than a "student issue," and that achieving academic integrity requires the commitment of all stakeholders in the academic community. Thus, the issue of building academic integrity concerns all levels of education and all entities.

However, special attention should be paid to the issue of violation of academic integrity in research activity. For example, in South Africa, the training of $\mathrm{PhD}$ students is perceived as playing a crucial role in addressing the country's need to eradicate poverty and reduce inequality (Jili \& Masuku, 2017). Thus, poor quality research hinders the development of science and technology, and hampers social progress.

According to statistical studies, plagiarism is the most common violation of academic integrity in research activities. It has been found that $93 \%$ of postgraduate students practice plagiarism in some form, and, on average, $50 \%$ of dissertations do not meet minimum academic quality standards, or contain plagiarism, or both (Organisation for Economic Co-operation and Development, 2017).

Reviewing research papers enables identification of the main factors that create opportunities for violation of academic integrity principles:

(1) Regulatory uncertainty. Among the problems of regulations are uncertainties about the algorithms used to detect academic dishonesty, and penalties for dishonesty at the legislative level. There is also a problem of withholding Bachelor's or Master's degrees or titles for violations of academic integrity.

(2) Culture of dishonesty. Academic integrity is an ethical issue (Simola, 2017). Developing intolerance for manifestations of dishonesty in research papers is primarily about developing a system of personal values and motivation for learning and professional activities. It should be noted that 
developing a culture of academic integrity is not the task of higher education only, but of all levels of education.

(3) Impunity. Even for proven cases of dishonest research practice, the relevant authorities often fail to enforce accountability for academic dishonesty (Rezvan et al., 2020). Acting with impunity regarding plagiarism usually implies other violations too (Kvit, 2020). Consequently, scientists continue to commit academic integrity violations in their research activities, apply new tactics to 'bypass' software to detect plagiarism, and continue publishing and defending low-quality research papers that have little scientific novelty and practical significance.

Lack of effective tools. Software with the technical ability to detect signs of plagiarism in papers is central to the detection of academic dishonesty (Sobhagyawati, 2017). The lack of clear algorithms for verifying research texts, and lack of repositories for their storage contributes further to manifestations of academic fraud.

(5) Distance online education presents even more opportunities for academic dishonesty, especially for ensuring academic integrity (Gamage et al., 2020).

The issues of regulatory uncertainty, impunity and lack of tools are objective factors that should be considered when developing a culture of academic integrity. Mastery by students of the educational component of curricula that train PhDs, and executing supervised research activities directly influence the development of a culture of academic integrity. Thus, the academic advisor not only monitors the postgraduate student's adherence to academic integrity principles, but also directly shapes its culture. Research has found that, "after the first year, most graduate students do not want to continue their studies due to low interest and support from their scientific advisor" (Semenog, 2016, p. 42). Gray and Jordan (2012) note that there is now a need for enhanced study on the role academic advisors play in shaping students' perceptions of academic integrity.

The literature provides no single classification of forms/styles of behavior required of academic advisors and postgraduate students. Semenog and Vovk (2016) identify three forms of academic advising: supervision, discussion, and counselling, while Kuklina (2006) distinguishes only two forms of academic advising: minimalist and formal. In their research on the views of postgraduate students and academic advisors on academic advising, Murphy et al. (2007) conclude that most attitudes and beliefs are related to a need for and expectations of regular monitoring. Talanova (2010) identifies eight roles of an academic advisor: assistant, teacher, psychologist, organizer, scientist, consultant, tutor and expert. Piekhota and Yermakova (2013) suggest levels for specific, appropriate pedagogical influence and assistance in the organization and during implementation of research: 1) full advising; 2) partial advising; 3) full counseling; 4) partial counseling.

A topical study is that by Agné and Mörkenstam (2018), which investigated the effectiveness of either collective or individual advising. They found that, during the first year of $\mathrm{PhD}$ studies, collective advising significantly increased the 
probability of a student completing the dissertation, and reduced the time needed to complete.

The model proposed by Gatfield (2005) is of interest to our study. It takes into account aspects of the interaction between the advisor and the postgraduate student, such as control and support. Based on these two dimensions - support and control (supervision) - Gatfield describes four styles of academic advising: pastoral, contractual, laissez-faire, and directorial. According to Gatfield (2005), none of these four styles should be considered undesirable or incorrect.

Thus, the growing need for scientists to adhere to the principles of academic integrity necessitate a study on the impact of academic advising style on the development of an academic integrity culture among PhD candidates, which was the aim of this study. The topicality of this direction was stimulated by social challenges resulting from the research problem, gaps in the practice of academic advising, the importance of preparing a new generation of academic staff, ensuring their mastery of skills related to conducting ethical research and defending postgraduate dissertations at the $\mathrm{PhD}$ level, and existing problems relating to plagiarism in research. The main questions arising from the topicality of this article and the problems of training PhD candidates, are the following:

1. What style of academic advising is the most common?

2. Is there a relationship between the academic advising style and the levels of academic integrity culture among $\mathrm{PhD}$ candidates?

\section{Methods and Materials}

The study was conducted between September 2019 and September 2020.

\subsection{Participants}

The subjects of the study were second-year postgraduate students of different specializations. The reason for targeting second-year students is that, by this time, postgraduate students have usually completed the education component of the Individual work plan of the graduate student, and are preparing the theoretical part of the dissertation.

The Volyn Institute of Postgraduate Pedagogical Education was chosen as the experimental base of the study. According to the State Statistics Service of Ukraine, 25245 postgraduate students were studying in Ukraine at the end of 2019 (Ukrstat, 2020). This number comprised the general population of our sample. Using an online calculator (with the parameters $85 \%$ confidence probability, $10 \%$ error), the size of a valid sample was determined to be 52 people. The study, thus, involved 52 postgraduate students and their 52 academic advisors. The study involved academic advisors who supervised only one postgraduate student each, in order to study the impact of academic advising style on the level of academic integrity of postgraduate students more effectively.

\subsection{Procedure of the Study}

The study was executed in three stages. The first (preparatory) stage included 
(1) The choice, justification and theoretical interpretation of the problem and research topic, as well as the study of previous research on the selected problem; and

(2) Development of the program and methods of conducting the experiment.

The second (main) stage involved

(1) Conducting a survey of academic advisors to determine their advising style (Appendix A);

(2) Conducting a survey of postgraduate students in order to determine the level of their academic integrity culture (Appendix B).

The third (final) stage involved

(1) Processing data that had been collected, using the Statistica software package;

(2) Interpreting statistical indicators;

(3) Comparing the actual results with those expected, and relating it to previous research on the selected problem; and

(4) Developing recommendations and documenting research outcomes.

\subsection{Data Processing}

In accordance with the objectives of each stage of the study, we used general empirical scientific methods of analysis, i.e., we conducted an experiment with qualitative and quantitative analysis of results, applied methods of mathematical data processing, in particular Pearson's $\mathrm{r}_{\mathrm{xy}}$ correlation coefficient, to determine the dependence and ANOVA (analysis of variance) to confirm the relationship between academic advising style and levels of the academic integrity culture among PhD candidates. The statistical analysis software package Statistica was used for quantitative data analysis.

Based on the Gatfield study (2005), we developed a closed-ended anonymous questionnaire with answer options on a 10-point scale for academic advisors, which allowed us to determine their dominant academic advising style (pastoral, contractual, laissez-faire or directorial). The survey consisted of 16 multiple choice questions, with each answer representing one of the four types of academic advising style for postgraduate students' work management and advisors' personal interaction with them. The maximum possible points is 160, which relates to an extremely high level of pastoral advising style. Other types of academic advising were estimated in a diversified manner. For instance, advisors with a laissez-faire style are characterized by low levels of support and providing limited levels of motivation and management skills (low motivation and management skills of supervisors impact postgraduate students' behavioral traits). Advisors with a low level of directorial style of academic supervision do not engage in high levels of personal interaction - these advisors may appear uncaring and uninvolved (for detailed information see Gatfield, 2005). Before the 
survey was used for practical purposes, it was tested by a number of formal criteria to determine reliability and validity.

The next step was to determine the tools for measuring the levels of academic integrity culture of postgraduate students (Appendix B). Based on the conducted analysis of scientific work we determined that the main components of academic integrity are knowledge of academic integrity, academic writing skill and ability, motivation, and values regarding the commission of academic misconduct. The components, furthermore, served as material for determining the criteria and indicators of the level of academic integrity culture of postgraduate students.

The level of the academic integrity culture of postgraduate students was determined using an open-ended questionnaire (Appendix B), which had been created and implemented using MyTest software and which diagnosed multiple aspects of academic integrity culture and the leading motives for research activity, such as social utility, professional advancement, material wellbeing, comfort, career benefits, creativity, and communication. These motives were determined using the measure called Motivation of Research Activity (Reheilo \& Bazeliuk, 2015). The level of the activity and cognitive criteria was determined using the questionnaire that required postgraduate students to give their own explanations of the research problem. After the questionnaire had been administered, the results were scored by the authors of the current study to determine students' levels of academic integrity culture. The number of points scored was categorized according to certain levels of academic integrity culture.

\section{Results}

Criteria for the levels of academic culture are axiological and motivational, cognitive, and activity. According to these criteria, the indicators and three levels of the academic integrity culture among $\mathrm{PhD}$ candidates were determined as either high, sufficient or medium (Table 1).

Table 1: Criteria and indicators for determining the levels of academic integrity culture among PhD candidates (developed by authors)

\begin{tabular}{|c|l|l|l|}
\hline \multicolumn{1}{|c|}{ Criteria } & \multicolumn{1}{|c|}{$\begin{array}{c}\text { Axiological and } \\
\text { motivational }\end{array}$} & \multicolumn{1}{|c|}{ Activity } & \multicolumn{1}{c|}{ Cognitive } \\
\cline { 1 - 3 } Indicators & $\begin{array}{l}\text { Postgraduate } \\
\text { students aim to obtain } \\
\text { professional } \\
\text { knowledge; they } \\
\text { carry out high-quality } \\
\text { scientific research, } \\
\text { High level work in the } \\
\text { and } \\
\text { research field. They } \\
\text { are internally } \\
\text { motivated to obtain } \\
\text { quality professional } \\
\text { knowledge. }\end{array}$ & $\begin{array}{l}\text { Postgraduate students } \\
\text { have perfect academic } \\
\text { writing skills and } \\
\text { ability, and carry out } \\
\text { high-quality research } \\
\text { activities. }\end{array}$ & $\begin{array}{l}\text { Postgraduate students } \\
\text { have extensive } \\
\text { knowledge and } \\
\text { understanding of the } \\
\text { laws and general and } \\
\text { group norms that } \\
\text { govern issues of } \\
\text { academic ethics, and } \\
\text { are well aware of } \\
\text { their responsibility to } \\
\text { avoid violating } \\
\text { academic integrity. }\end{array}$ \\
\hline $\begin{array}{l}\text { Sufficient } \\
\text { level }\end{array}$ & $\begin{array}{l}\text { Postgraduate } \\
\text { students want to }\end{array}$ & $\begin{array}{l}\text { Postgraduate students } \\
\text { have sufficient }\end{array}$ & $\begin{array}{l}\text { Postgraduate students } \\
\text { have sufficient }\end{array}$ \\
\hline
\end{tabular}




\begin{tabular}{|l|l|l|l|}
\hline & $\begin{array}{l}\text { acquire professional } \\
\text { knowledge and } \\
\text { defend a dissertation, } \\
\text { but are not sure about } \\
\text { further work in the } \\
\text { research field. Their } \\
\text { motives for scientific } \\
\text { activity are unstable. }\end{array}$ & $\begin{array}{l}\text { academic writing } \\
\text { skills and abilities, but } \\
\text { may make minor } \\
\text { mistakes. They carry } \\
\text { out research activities } \\
\text { at an adequate level. }\end{array}$ & $\begin{array}{l}\text { knowledge and } \\
\text { understanding of the } \\
\text { laws and general and } \\
\text { group norms that } \\
\text { govern issues of } \\
\text { academic ethics. They } \\
\text { do not fully realize } \\
\text { their responsibility for } \\
\text { avoiding violating } \\
\text { academic integrity. }\end{array}$ \\
\hline \multirow{5}{*}{$\begin{array}{l}\text { Medium } \\
\text { level }\end{array}$} & $\begin{array}{l}\text { Postgraduate } \\
\text { students are not keen } \\
\text { to obtain professional } \\
\text { knowledge, or to } \\
\text { carry out high-quality } \\
\text { scientific research. } \\
\text { They plan no further } \\
\text { work in the research } \\
\text { field, and their } \\
\text { postgraduate studies } \\
\text { are driven mostly by } \\
\text { external motives. }\end{array}$ & $\begin{array}{l}\text { Postgraduate students } \\
\text { have academic } \\
\text { writing skills and } \\
\text { abilities, but make } \\
\text { significant mistakes } \\
\text { when citing sources. } \\
\text { They carry out } \\
\text { research activities at a a } \\
\text { medium level. }\end{array}$ & $\begin{array}{l}\text { Postgraduate students } \\
\text { have mediocre } \\
\text { knowledge and } \\
\text { understanding of the } \\
\text { laws and general and } \\
\text { group norms that } \\
\text { govern academic } \\
\text { ethics. They do not } \\
\text { realize their } \\
\text { responsibility for } \\
\text { avoiding violating } \\
\text { academic integrity. }\end{array}$ \\
\hline
\end{tabular}

The study used various diagnostic techniques, taking into account the peculiarities of the studied phenomenon, to determine the levels of the components of the academic integrity culture among $\mathrm{PhD}$ candidates, namely, axiological and motivational, activity, and cognitive.

We also surveyed 52 academic advisors to determine their advising styles. Table 2 shows the data obtained.

Table 2: Results of a survey of academic advisors to determine their advising style

\begin{tabular}{|l|c|c|}
\hline Academic advising style & Number & $\mathbf{\%}$ \\
\hline Pastoral style & 9 & 17.3 \\
\hline Laissez-faire style & 6 & 11.5 \\
\hline Contractual style & 21 & 40.4 \\
\hline Directorial style & 16 & 30.8 \\
\hline
\end{tabular}

The diagnostics show that $40.4 \%$ of academic advisors applied the contractual advising style, and $30.8 \%$ of academic advisors preferred the directorial style. The pastoral style was less common (17.3\% of respondents), and $11.5 \%$ of surveyed advisors practiced the laissez-faire style. Thus, most academic advisors exercised detailed control over postgraduate students' research activities. The main difference between the two most prevalent styles is the personal communication style involved; it is either a formal (directorial style) or friendly relationship (contractual) between the academic advisor and the $\mathrm{PhD}$ candidate.

Table 3 presents the results of the experimental measurement. 
Table 3: Levels of academic integrity culture among $\mathrm{PhD}$ candidates by criterion

\begin{tabular}{|l|l|c|c|}
\hline Criteria & Levels & Number & \% \\
\hline \multirow{3}{*}{$\begin{array}{l}\text { Axiological and } \\
\text { motivational }\end{array}$} & High & 19 & 36.5 \\
\cline { 2 - 4 } & Sufficient & 28 & 53.8 \\
\cline { 2 - 4 } & Medium & 5 & 9.7 \\
\hline \multirow{3}{*}{ Activity } & High & 15 & 28.8 \\
\cline { 2 - 4 } & Sufficient & 31 & 59.6 \\
\cline { 2 - 4 } & Medium & 6 & 11.6 \\
\hline \multirow{3}{*}{ Cognitive } & High & 13 & 25 \\
\cline { 2 - 4 } & Sufficient & 34 & 65.3 \\
\cline { 2 - 4 } & Medium & 5 & 9.7 \\
\hline
\end{tabular}

Analysis of the axiological and motivational criterion shows that the majority of postgraduate students exhibited a sufficient level of this criterion - 53.8\% - while $36.5 \%$ of postgraduate students exhibited a high level, and $9.7 \%$ of respondents a medium level. Thus, postgraduate students aimed to gain professional knowledge and obtain PhD degrees, though their research was mostly guided by personal motives.

The results of the respondents on the cognitive criterion indicate that $\mathrm{PhD}$ candidates were well aware of the concept and principles of academic culture, knew the laws and norms governing academic ethics, and were aware of their responsibility for avoiding violating academic integrity. A quarter of respondents exhibited a high level on the cognitive criterion, $65.3 \%$ of respondents had a sufficient level, and $9.7 \%$ of postgraduate students had a low level.

Diagnosis of the activity criterion found that $28.8 \%$ of postgraduate students adhered to the principles of academic integrity culture at a high level, 65.3\% exhibited a sufficient level of adherence, and $11.6 \%$ among PhDs adhered at a medium level. Thus, graduate students need further training to master the skills of academic writing, as they make mistakes in presenting the results of their research, which affects the quality of scientific work.

These results were generalized and systematized, which enabled us to determine the number of postgraduate students at each of the three levels of academic culture (see Table 4).

Table 4: Levels of academic culture among PhD candidates

\begin{tabular}{|l|c|c|}
\hline Levels & Number & \% \\
\hline High & 16 & 30.7 \\
\hline Sufficient & 30 & 57.8 \\
\hline Medium & 6 & 11.5 \\
\hline
\end{tabular}

The distribution of the surveyed postgraduate students by level of academic integrity culture is as follows: $57.8 \%$ of respondents had a sufficient level of academic culture, $30.7 \%$ had a high level, and $11.5 \%$ of PhD candidates had a medium level. This distribution suggests that it may be necessary to continue developing an academic integrity culture at the level of PhD in higher education. 
Mistakes by postgraduate students could degrade the quality of scientific research. It should be noted that most postgraduate students who enter $\mathrm{PhD}$ studies have Master's degrees with excellent scores. The results could, thus, indicate gaps in the Master's program, during which students failed to develop an academic integrity culture.

The results obtained for the academic integrity culture of postgraduate students were correlated with the data obtained on the academic advising style of advisors (Table 5).

Table 5: The ratio of the levels of academic integrity culture of postgraduate students to the number of academic advisors with different advising styles

\begin{tabular}{|c|c|c|c|c|c|}
\hline $\begin{array}{l}\text { Item } \\
\text { No. }\end{array}$ & $\begin{array}{l}\text { Academic } \\
\text { advising style }\end{array}$ & $\begin{array}{c}\text { Number } / \\
\% \text { of } \\
\text { academic } \\
\text { advisors }\end{array}$ & $\begin{array}{l}\text { Levels of } \\
\text { academic } \\
\text { culture }\end{array}$ & $\begin{array}{l}\text { Number of } \\
\text { postgraduate } \\
\text { students }\end{array}$ & $\%$ \\
\hline \multirow[t]{3}{*}{1.} & \multirow[t]{3}{*}{ Pastoral style } & \multirow[t]{3}{*}{$9 / 17,3 \%$} & High & 1 & 11.1 \\
\hline & & & Sufficient & 5 & 55.6 \\
\hline & & & Medium & 3 & 33.3 \\
\hline \multirow[t]{3}{*}{2.} & \multirow{3}{*}{$\begin{array}{l}\text { Laissez-faire } \\
\text { style }\end{array}$} & \multirow[t]{3}{*}{$6 / 11,5 \%$} & High & 1 & 16.6 \\
\hline & & & Sufficient & 3 & 50 \\
\hline & & & Medium & 2 & 33.4 \\
\hline \multirow[t]{3}{*}{3.} & \multirow{3}{*}{$\begin{array}{l}\text { Contractual } \\
\text { style }\end{array}$} & \multirow[t]{3}{*}{$21 / 40,4 \%$} & High & 7 & 33.3 \\
\hline & & & Sufficient & 14 & 66.7 \\
\hline & & & Medium & 0 & - \\
\hline \multirow[t]{3}{*}{4.} & \multirow{3}{*}{$\begin{array}{l}\text { Directorial } \\
\text { style }\end{array}$} & \multirow[t]{3}{*}{$16 / 30,8 \%$} & High & 5 & 31.3 \\
\hline & & & Sufficient & 8 & 50 \\
\hline & & & Medium & 3 & 16.7 \\
\hline
\end{tabular}

The results show that the academic advisors with:

(1) A contractual style had the highest percentage of postgraduate students with a high level of academic integrity culture - 33.3\%;

(2) Advisors with a directorial style had $31.3 \%$ of the postgraduate students with a high level of academic integrity culture;

(3) Advisors with a laissez-faire style of academic advising had $16,6 \%$ of postgraduate students with high level of academic integrity culture.

(4) Academic advisors with a pastoral advising style had the lowest percentage $(11,1 \%)$ of postgraduate students with a high level of academic integrity culture.

According to this data, the contractual style of academic advising might be regarded as the most advanced in terms of encouraging a high level of academic integrity culture $(33,3 \%$ of students of advisors with this style had a high level of academic integrity culture). The weakest style in terms of encouraging a high level of academic integrity culture was the pastoral style $(11,1 \%$ of students with a high 
level of academic integrity culture). Moreover, it is clear that most academic advisors tend to use the contractual style, which seems to have the greatest mutual benefits for advisors and students.

The data shows that personal relationships with and control over the research of postgraduate students create conditions that could prevent violations of academic integrity. If postgraduate students know that their work will be thoroughly checked by their academic advisors, they are likely to deliberately prevent plagiarism or falsifications.

Most postgraduate students with a sufficient level of academic integrity culture have advisors with a contractual advising style $-66.7 \%$. It is noteworthy that the representatives of this advising style have no postgraduate students with a medium level of academic integrity culture. The data allows us to conclude that friendly relations and clear control and guidance of postgraduate students' work are favorable for preparing high-quality, relevant research that is scientifically novel. Of the postgraduate students with advisors with a pastoral advising style, $56 \%$ were students with a sufficient level of academic integrity culture; similarly, $50 \%$ of the students of advisors with laissez-faire and directorial styles had a sufficient level of academic integrity culture.

Equal percentages of students with a medium level of academic integrity culture (33.3\%) had advisors with pastoral and laissez-faire styles of advising. Limited interaction on personal and education levels fails to stimulate postgraduate students to adhere to academic integrity principles, and limited control by the advisor contributes to shortcomings in the preparation and conduct of research.

To determine whether there is a relationship between academic advising style and level of academic integrity culture among PhD candidates, we applied the Pearson $r_{x y}$ correlation coefficient. The value of the Pearson's $r_{x y}$ correlation coefficient is determined by the formula:

$$
r_{x y}=\frac{\Sigma\left(x_{i}-\bar{x}\right) \cdot\left(y_{i}-\bar{y}\right)}{(n-1) \cdot s_{x} \cdot s_{y}}
$$

We advanced the following hypotheses:

(1) $\quad \mathrm{H}_{0}$ is based on the assumption that there is no relationship between academic advising style and the level of academic integrity culture among PhD candidates;

(2) $\quad \mathrm{H}_{1}$ is based on the assumption that a relationship between academic advising style and the level of academic integrity culture among $\mathrm{PhD}$ candidates exists.

The empirical value of Pearson's $r_{x y}$ correlation coefficient is 0.343 . Let us check its statistical significance. According to the table of critical values of Pearson's $r_{x y}$, correlation coefficient for $\mathrm{df}=\mathrm{n}=52$ and given $\alpha=0.05$, we find $\mathrm{r}_{\text {crit. }}=0.273$. Since $\left|r_{e m p}\right|>r_{\text {crit. }}(0.343>0.273)$, hypothesis $H_{0}$ is rejected. 
The effect size is estimated by the coefficient of determination $r^{2}=r_{x y}{ }^{2}=0.343^{2}=$ 0.118. According to J. Cohen's interpretation, the size of the effect corresponds to a large extent. In other words, the total variability of the variables is $11.8 \%$.

Pearson's correlation coefficient enabled us to reject the null hypothesis for a given data set $\left(\mathrm{r}_{\mathrm{xy}}=0.343 ; \mathrm{p}<.05 ; \mathrm{n}=52\right)$. There is a statistically significant positive correlation between academic advising style and the level of academic integrity culture among PhD candidates. According to J. Cohen's interpretation, the size of the effect corresponds with the average level $\left(\mathrm{r}^{2}=0.118\right)$.

Figure 1 demonstrates the relationship between the estimated values of the level of academic integrity of students and advisors' advising styles.

In addition to correlation analysis, which only shows the data correlation density, but not its direction, a regression analysis was conducted to determine the percentage of the academic advising style that explains the level of academic integrity culture, and whether this relationship is direct or inverse.

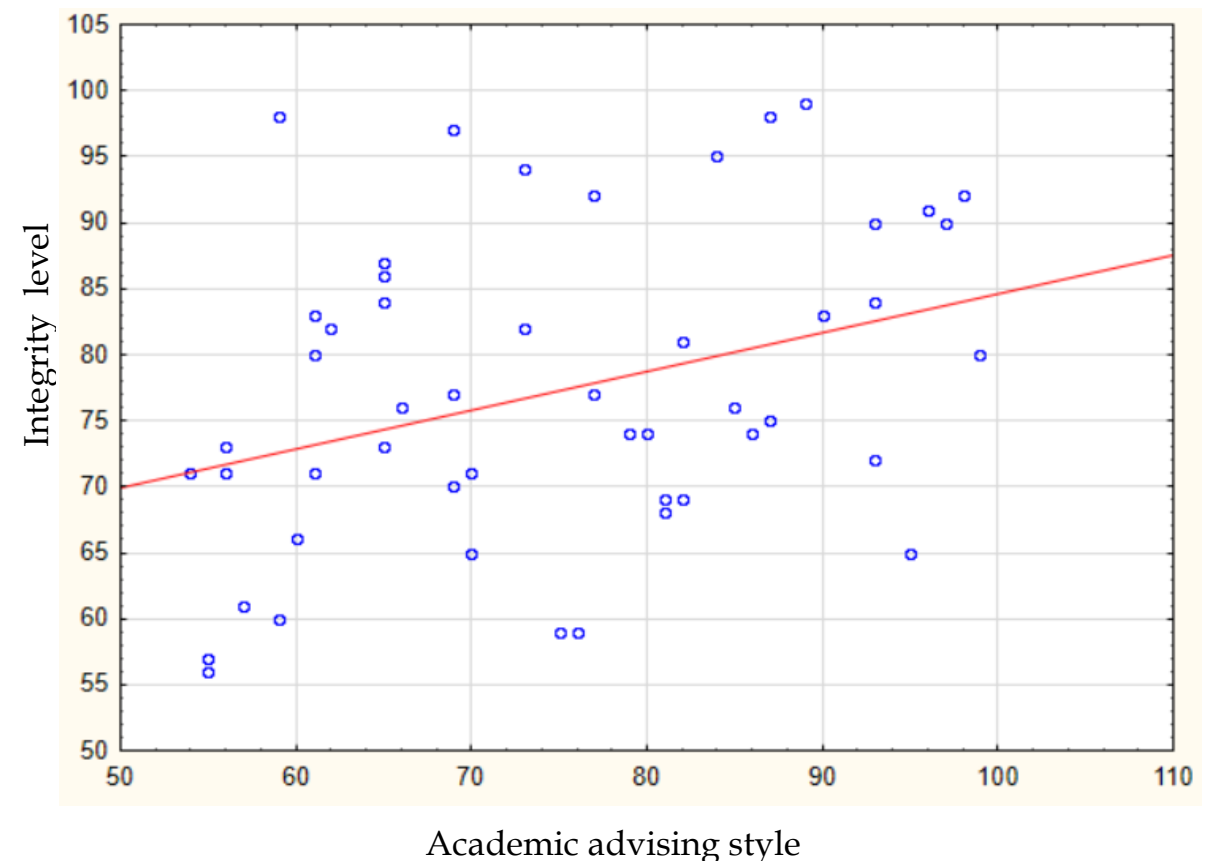

Figure 1 : The relationship between the academic integrity culture level and the academic advising style

To estimate the dependence, which we assumed to exist at a theoretical level, the best specification was a nonlinear quadratic dependence. The method of regression analysis involves building an equation that determines the dependence of one indicator (dependent variable, $\mathrm{Y}$ ) on a particular factor (independent variable, $\mathrm{X}$ ). The ordinary least squares (OLS) method was used to estimate the coefficients (parameters) of the regression equation. The regression equation was as follows: 
where

$$
Y_{i}=b_{0}+b_{1} X^{2}{ }_{i}
$$

$Y_{i}$ - dependent variable, the academic integrity level;

$b_{0}$ - cross-section coefficient;

$b_{1}$ - coefficient for the dependent variable; and

$X_{i}$ - independent variable, academic guidance style.

Tables 6 and 7 present the main econometric results of the estimated model.

Table 6: The main results of the linear regression model

\begin{tabular}{|c|c|c|c|c|}
\hline Model & R & R Square & $\begin{array}{c}\text { Adjusted R } \\
\text { Square }\end{array}$ & $\begin{array}{c}\text { Std. Error of } \\
\text { the Estimate }\end{array}$ \\
\hline 1 & $.442^{\mathrm{a}}$ & .317 & .300 & 10.97239 \\
\hline
\end{tabular}

Table 7: Estimated coefficients of the model

\begin{tabular}{|c|c|c|c|c|c|c|}
\hline & \multirow{2}{*}{ Model } & \multicolumn{2}{|c|}{$\begin{array}{l}\text { Unstandardized } \\
\text { Coefficients }\end{array}$} & \multirow{2}{*}{$\begin{array}{c}\begin{array}{c}\text { Standardized } \\
\text { Coefficients }\end{array} \\
\text { Beta }\end{array}$} & \multirow{2}{*}{$\mathbf{t}$} & \multirow{2}{*}{ Sig. } \\
\hline & & B & Std. error & & & \\
\hline \multirow{2}{*}{1} & (Constant) & 55.185 & 8.714 & & 6.333 & .000 \\
\hline & Academic integrity & .294 & .114 & .342 & 2.576 & .013 \\
\hline
\end{tabular}

Therefore, the specified model was as follows:

$$
Y_{i}=55,19+0,29 X^{2}
$$

That is, the double change of the independent variable $X_{i}$ has a direct positive effect on the dependent variable $Y_{i} 0,29 * 4=1.16$ times.

The most important calculation of the regression model is the coefficient of determination $\mathrm{R}$ Square, which shows how much the variance of the dependent variable (Academic integrity level) is due to a change in the variance of the independent variable (Academic advising style). In our case, it is $32 \%$, which is considerable, and confirms the relationship between variables. Since the significance level for the two coefficients is much less than 0.05 , both coefficients are statistically significant, therefore, our model is adequate.

A variance analysis was also performed, according to which hypothesis $\mathrm{H}_{0}$ is the equality of the mean at different levels, that is, the independence of the values of advising style and, accordingly, academic integrity culture level (see Table 8). 
Table 8: ANOVA univariate tests of significance for academic integrity culture level

\begin{tabular}{|c|l|c|c|c|c|c|}
\hline \multirow{2}{*}{\multicolumn{2}{|c|}{ Effect }} & \multicolumn{5}{|c|}{$\begin{array}{c}\text { Sigma-restricted parameterization. } \\
\text { Effective hypothesis decomposition }\end{array}$} \\
\cline { 3 - 7 } & SS & $\begin{array}{c}\text { Degrees of } \\
\text { Freedom }\end{array}$ & MS & Fisher & p \\
\hline \multirow{2}{*}{1} & Intercept & 253051.1 & 1 & 253051.1 & 2495.779 & 0.000000 \\
\cline { 2 - 7 } & Advising style & 4790.8 & 31 & 154.5 & 1.524 & 0.016331 \\
\hline & Error & 2027.8 & 20 & 101.4 & & \\
\hline
\end{tabular}

Thus, for hypothesis $\mathrm{H}_{0}$, the critical value of $\mathrm{p}$-value $=5 \%$ is rejected, because Table 8 shows the differences in means by Fisher's criterion are statistically significant, and the possibility of error is close to 0 . We present the graph in Figure 2 to show how the means changed. Analysis of variance confirms the results of other analyses: an increase in the values of advising style corresponding to the contractual type entails increased values of the academic integrity culture level.



Figure 2: Change in the mean value of the level of academic integrity culture Note: Academic advising style; LS Means; Current effect: $\mathrm{F}(31,20)=1,5242, \mathrm{p}=, 16334$ Effective hypothesis decomposition; Vertical bars denote 0.95 confidence intervals.

\section{Discussion}

In answering the questions of our study, we must note further positions. Diagnostic results show that $40.4 \%$ of academic advisors used the contractual advising style, and $30.8 \%$ of advisors used a directorial style, thus, these two are the most common academic advising styles. The results obtained coincide with the results obtained by Zerchaninova and Tarbeeva (2020). However, we agree with Gatfield (2005) that none of the styles can be considered ideal and correct, and that styles can and should change according to the situation or an advisor's 
own advising model (Qureshi \& Neelofar, 2016). Other researchers have found that managers should be dynamic and not use only one approach (Jili \& Masuku, 2017); the approach should be determined by changes in the postgraduate students' work style. We share the opinion of Zerchaninova and Tarbeeva (2020), that the academic advisor should regulate the advising style in accordance with the year of study of the postgraduate student, and the peculiarities of the educational and scientific component of training.

As far as the second research question is concerned, there is a medium relationship between the academic advising style and level of academic integrity culture among $\mathrm{PhD}$ candidates. This relationship is not linear, and we cannot argue that academic advisors with a contractual leadership style (who had the most students with high levels of academic integrity culture) adhere to all the principles of academic integrity culture. In our opinion, and according to the data obtained, an academic advisor has a direct influence on the development of an academic integrity culture, because advisors work directly with postgraduate students during the preparation of their dissertations.

After all, according to Gatfield (2005), the contractual style assumes that academic advisors provide personal support to postgraduate students, and manage the process of preparing students' research papers effectively. Thus, the nature of the interaction of the academic advisor with the postgraduate student plays a significant role in the process of professional training of the student, and affects the personal satisfaction of postgraduate students related to the process of $\mathrm{PhD}$ training. A study conducted by Cockrell and Shelley (2011) found a positive correlation between the level of satisfaction of postgraduate students in the process of training at postgraduate level and the nature of the relationship with the academic advisor. This also confirms an assertion by Igumbor et al. (2020) that it is important for a student to 'match' with the academic advisor, both personally (have a good relationship), and academically, which is, to a large degree, the case for the contractual advising style.

We agree with Gray and Jordan (2012) that there are two separate and interrelated roles that an academic advisor should play to promote an academic integrity culture in students. On the one hand, the academic advisor should be a mentor who promotes academic integrity among students in general and, on the other hand, the advisor should promote ethical principles, so that students will act honestly at a particular/practical level.

Previous research has not, to date, addressed the problem related to the relationship between academic advising style and the level of academic integrity culture of postgraduate students - this study was a first. The study was complex, as it involved two pedagogical categories and their relationship. The outlined results will be useful for academic advisors, highly qualified specialists, guarantors of educational programs and heads of postgraduate departments, as well as professionals who provide psychological services at universities. In our opinion, it is important to enshrine the performance indicators of academic advisors at the regulatory level, and to provide sufficient academic and 
psychological support, in order to prevent the manifestations of academic plagiarism.

\section{Conclusion}

The need to develop an academic integrity culture in PhD candidates is urgent. The factors that create opportunities for violation of academic integrity principles, as well as an absence of studies on the impact of the academic advising style on the development of academic integrity culture in postgraduate students, created the background for this experiment.

The level of training postgraduate students at $\mathrm{PhD}$ level receive depends mainly on the requirements of academic advisors, their knowledge of the research topic, and the frequency and effectiveness of beginner researchers' consultations with their academic advisors. The academic advisor must apply a creative approach to working with postgraduate students. Literature suggests that the academic advisor should be flexible when working with postgraduate students, and should choose advising styles according to emerging conditions or circumstances. The results obtained by this study helped us to determine the main guidelines.

The main findings of the study are as follows. The diagnostics of academic advising style determine that the pastoral academic advising style was applied by $17,3 \%$ of advisors, the laissez-faire style by $11,5 \%$, the contractual style by $40,4 \%$, and the directorial style by $30,8 \%$ of advisors. Comparing these findings with postgraduate students' level of academic integrity culture lead us to conclude that the contractual style of academic advising could be regarded as the most beneficial in terms of raising the level of academic integrity culture of postgraduate students (33,3\% of students with advisors with this style of advising, had a high level of academic integrity culture). The weakest style for promoting academic integrity culture is the pastoral style (only $11,1 \%$ of students with advisors with this style had high levels of academic integrity culture). Moreover, most academic advisors (40,4\%) applied the mutually beneficial contractual style. Analysis of variance confirms the results of other analyses: a quantitative increase in the indicators of advising style corresponds with the contractual type, and entails increased values in the academic integrity level. This relationship is not linear, and we cannot argue that an academic advisor with a contractual leadership style adheres to all the principles of good academic integrity culture. The study concludes that there is a medium relationship between academic advising style and level of academic integrity culture among PhD candidates.

\section{Recommendations}

The study was the first attempt to determine whether there is a relationship between the academic advising style of advisors and the level of academic integrity culture among PhD candidates. To develop the problem further, we

recommend conducting this type of research at the first (Bachelor's) and second (Master's) degree levels of higher education.

The results obtained can serve as background for further research, and can be used to improve the training of $\mathrm{PhD}$ candidates. The experiment did not, however, 
cover all aspects of the problem. Further research could investigate trends in the choice of academic advising style in accordance with the postgraduate students' further teaching and research experience, and explore, in detail, the relationship between the level of academic integrity culture of the academic advisor and postgraduate student respectively. In addition, it is advisable to determine whether there are differences between the dominant types of academic advising styles, the levels of postgraduate students' academic integrity culture, and areas of training (and academic specialties) at postgraduate educational levels.

According to the findings of the research, it is advisable, when training PhD candidates, to (1) conduct constant monitoring of graduate students' satisfaction with the style of their advisors' academic advising; (2) carry out professional training of academic advisors who conduct academic advising for the first time; (3) develop an appropriate program to promote an academic integrity culture in PhD candidates; (4) determine, revise and constantly improve training programs for postgraduate students, in view of current trends in the development of an academic integrity culture in PhD candidates.

While conducting further studies, it is essential to take into account the level of influence of other staff in postgraduate students' level of academic integrity culture. In general, the number of variables should be increased, to provide more complete and reliable data.

\section{Research Limitations}

The main limiting factors of the study are as follows: The experimental work was conducted for second-year postgraduate students only, the study did not take into account the work experience of academic advisors, and the limited time allocated for the experiment.

\section{References}

Agné, H., \& Mörkenstam, U. (2018). Should first-year doctoral students be supervised collectively or individually? Effects on thesis completion and time to completion. Higher Education Research $\mathcal{E}$ Development, 37(4), 669-682. https://doi.org/10.1080/07294360.2018.1453785

Artyukhov, A., Liuta, O. (2017). Academic integrity in Ukrainian higher education: values, skills, actions. Business Ethics and Leadership, 1(1), 34-39. https://doi.org/10.21272/bel.2017.1-04

Bretag, T. (2018, April 26). Academic integrity. Oxford Research Encyclopedias. https://doi.org/10.1093/acrefore/9780190224851.013.147

Cockrell, C. N., \& Shelley, K. (2011). The relationship between academic support systems and intended persistence in doctoral education. Journal of College Student Retention: Research, Theory \& Practice, 12(4), 469-484.

Faucher, D., \& Caves, S. (2009). Academic dishonesty: Innovative cheating techniques and the detection and prevention of them. Teaching and Learning in Nursing, 4(2), 3741. doi:10.1016/j.teln.2008.09.003

Gamage, K. A. A., Silva, E. K. D., \& Gunawardhana, N. (2020). Online delivery and assessment during COVID-19: Safeguarding academic integrity. Education and Science, 10, 301. https://doi.org/10.3390/educsci10110301 
Gatfield, T. (2005). An investigation into PhD supervisory management styles: Development of a dynamic conceptual model and its managerial implications. Journal of Higher Education Policy and Management, 27(3), 311-325.

Gray, P. W., \& Jordan, S. R. (2012). Supervisors and academic integrity: Supervisors as exemplars and mentors. Journal of Academic Ethics, 10(4), 299-311. https:/ / doi.org/10.1007/s10805-012-9155-6

Igumbor, J. O., Bosire, E. N., Karimi, F., Katahoire, A., Allison, J. A., Muula, S. A., Peixoto, A., Otwombe, K., Gitau, E., Bondjers, G., Fonn, S., \& Ajuwon, A. (2020). Effective supervision of doctoral students in public and population health in Africa: CARTA supervisors' experiences, challenges and perceived opportunities. Global Public Health, 16(3), 1-16. https:/ / doi.org/10.1080/17441692.2020.1864752

Jili, N. N., \& Masuku, M. M. (2017). Supervision as a tool of producing independent researchers: Reflecting on supervision processes. Ponte Academic Journal, 73(8). https://doi.org/10.21506/j.ponte.2017.8.25

Kuklina, V. (2006). The figure of the scientific supervisor and PhD thesis in the biography of a young humanist. Communitas, 2, 106-115.

Kvit, S. (2020, March 9). The national agency for higher education quality assurance for protecting academic integrity in Ukraine. Serhiy Kvit's personal journal. https:/ / kvit.ukma.edu.ua/2020/03/the-national-agency-for-higher-educationquality-assurance-for-protecting-academic-integrity-in-ukraine/

Murphy, N., Bain, J. D., \& Conrad, L. (2007). Orientations to research higher degree supervision. Higher Education, 53(2), 209-234. https://doi.org/10.1007/s10734005-5608-9

Organisation for Economic Co-operation and Development. (2017). OECD reviews of integrity in education: Ukraine 2017. OECD.

Piekhota, O. \& Yermakova, I. (2013). Основи педагогічних досліджень [Fundamentals of pedagogical research]. Znannia.

Qureshi, R., \& Neelofar, V. (2016). Pedagogy of research supervision pedagogy: A constructivist model. Istraživanja u Pedagogiji, 6(2), 95-110.

Reheilo, I. Y., \& Bazeliuk, N. V. (2015). Освітня складова в докторських програмах у галузі освіти Гарвардського університету [Coursework in the Harvard University doctoral programs in education]. Вищза осbima в Украӥні/Higher Education of Ukraine, 3(2), 41-48. https:/ / www.researchgate.net/publication/301549006_Osvitna_skladova_v_do ktorskih_programah_u_galuzi_osviti_Garvardskogo_universitetu

Rezvan, O., Volkova, N., Kozhushko, S., \& Marusynets, M. (2020). Problems of academic dishonesty in higher education: ways of its preventing and eliminating. Espacios, 41(28), 194-206.

Sefcik, L., Striepe, M., \& Yorke, J. (2019). Mapping the landscape of academic integrity education programs: what approaches are effective? Assessment $\mathcal{E}$ Evaluation in Higher Education, 45(1), 30-43. https:/ / doi.org/10.1080/02602938.2019.1604942

Semenog, О. (2016). Академічна культура як фундаментальна частина підготовки кандидатів наук за спеціальністю 015 «Професійна освіта» [Academic culture as a fundamental part of training PhDs in the speciality 015 Professional education]. Sumy State Pedagogical University named after A.S. Makarenko.

Semenog, O., \& Vovk, M. (2016). Академічна культура дослідника в освітньому та культурному просторі університету [Academic culture of the explorer in the educational and cultural space of the university]. Sumy State Pedagogical University named after A.S. Makarenko.

Sheard, J., Morgan, M., Petersen, A., Settle, A., \& Sinclair, J. (2018, January). Informing students about academic integrity in programming. In R. Mason \& Simon (Eds.),

http://ijlter.org/index.php/ijlter 
Proceedings of the 20th Australasian Computing Education Conference, Brisbane, Australia (pp. 113-122). Association for Computing Machinery. https://doi.org/10.1145/3160489.3160502

Simola, S. (2017). Managing for academic integrity in higher education: Insights from behavioral ethics. Scholarship of Teaching and Learning in Psychology, 3(1), 4357. https://doi.org/10.1037/st10000076

Sobhagyawati, G. (2017). Emerging trends and technology in knowledge management. Prateeksha Publications.

Talanova, Z. V. (2010). Докторська підготовка у світі та в Україні [Doctoral training in the world and in Ukraine]. Millennium.

Ukrstat. (2020). Higher education in Ukraine in 2019. Statistical information. http://www.ukrstat.gov.ua/operativ/operativ2005/osv_rik/osv_u/vysh_osvit a/arch_vysh_osvita.htm

Zerchaninova, T. E. \& Tarbeeva, I. S. (2020). The role of the supervisor in the scientific and educational activities of the graduate student. Research Result. Series: Sociology and Management, 6(2), 145-158. https://doi.org/10.18413/2408-9338-2020-6-2-0-10 